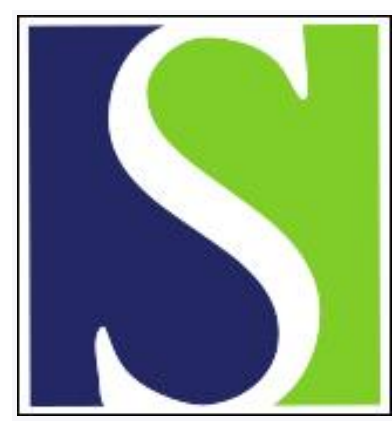

Scand J Work Environ Health 1980;6(3):1-124

https://doi.org/10.5271/sjweh.2640

Issue date: 1980

Stress in work. Conceptual analysis and a study on prison personnel.

by Kalimo R

Key terms: conceptual analysis; prison personnel; stress; work

This article in PubMed: www.ncbi.nlm.nih.gov/pubmed/7221508

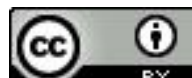




\section{Stress in work}

Conceptual analysis and a study on prison personnel

by Raija Kalimo

Institute of Occupational Health

SF-00290 Helsinki 29

Finland

and

University of Helsinki

Department of Psychology

SF-00170 Helsinki 17

Finland 


\section{Preface}

This report includes a review of stress theory and stress concepts and their application in an empirical occupational study. The aim of the study was to clarify the relationships between work stressors and also the stress reactions of working people. The report covers a third part of a study concerning the work conditions, stress and health of prison personnel. This study is one of several carried out by the Institute of Occupational Health, Helsinki, to clarify the possible psychic and social risk factors of health in work life. The Institute's director general Jorma Rantanen, $\mathrm{MD}$, and scientific director Sven Hernberg, MD, have been active in promoting this field of research.

The Prison Department of the Finnish Ministry of Justice and the Finnish Ministry of Finance initiated this research project concerning prision personnel. Matti Ylikoski, MD, from the Ministry of Finance and Kaarina Suonio, MA, ML, Kari Vanhala, PhD, and Martti Paloheimo, MD, from the Prison Department, played important roles in the planning of the study. The cooperation of the prison personnel, as the subjects of the study, was a prerequisite for the total project.

Helena Hänninen, PhL, from the Institute of Occupational Health, was the responsible scientist during the planning of the first phases of the study. She has given me valuable advice and support. Mailis Olkkonen (earlier Senne), MA, worked as a member of the research team and took care of much of the practical work involved in the data collection and handling.

Part of the study material is based on data from a health examination carried out by the mobile field clinic of the Institute of Occupational Health under the leadership of Ann-Lis Backman, MD, who also offered useful suggestions for the corresponding parts of the text.

One of the basic discussions about preparing this report was carried out with Prof R Olavi Viitamäki, who offered many encouraging and useful suggestions. Assistant professor Valde Mikkonen, $\mathrm{PhD}$, and docent Raimo Raitasalo, $\mathrm{PhD}$, read the entire manuscript and offered constructive criticism, which I highly appreciated during the revision of the manuscript.

Discussions at various stages with docent Esko Kalimo, PhD, Kari Lindström, PhL, and my colleagues, especially Pekka Huuhtanen, PhL, and Terhi Pöyhönen, MA, have provided me with great support. Erkki Nenonen, MA, gave invaluable help with the data processing Prof Veijo Virsu, $\mathrm{PhD}$, played an important role by constructively pressing me to finish the work.

Ms Arja Metsikkö did an important part of the whole by drawing the figures, Ms Iris Ovalo by typing the manuscripts, Donald Neville, BSc, by correcting the language, Prof Matti Rissanen, PhD, by checking the language, and Georgianna Oja, BA, by preparing the manuscript for publication.

I wish to offer my deepest thanks to all, as well as to the Institute of Occupational Health for its supportive attitude towards research work.

The study was financially supported by the Finnish Ministry of Finance.

Espoo, 22 October 1980

Raija Kalimo 


\section{CONTENTS}

\section{Introduction and objectives}

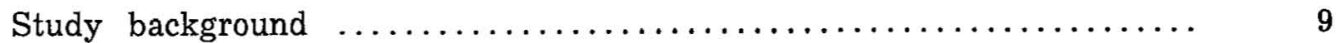

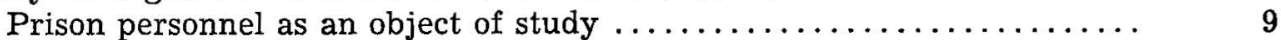

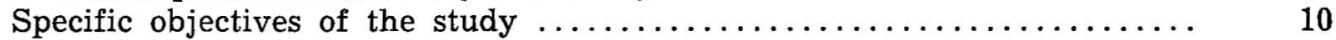

Structure of the report $\ldots \ldots \ldots \ldots \ldots \ldots \ldots \ldots \ldots \ldots \ldots \ldots \ldots \ldots \ldots \ldots \ldots, 11$

II Theoretical framework of the study

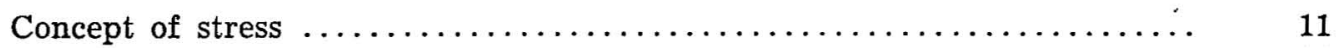

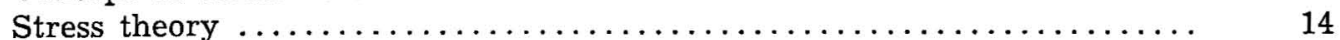

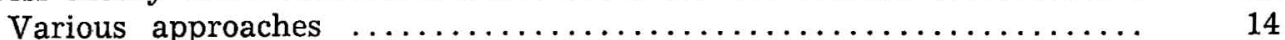

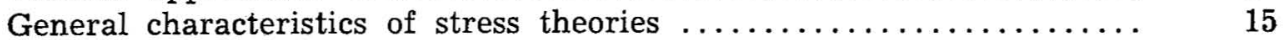

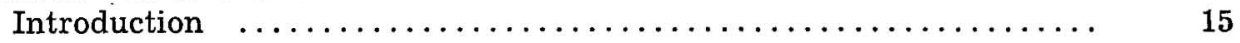

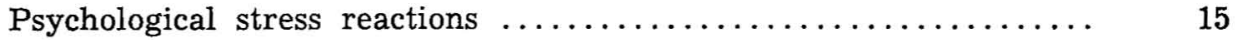

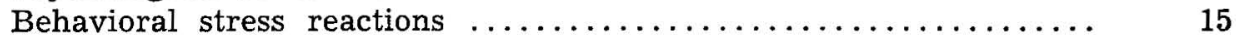

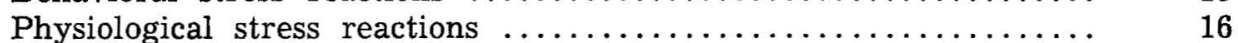

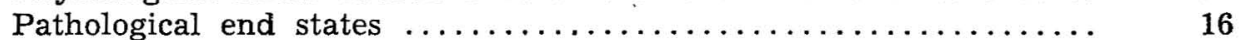

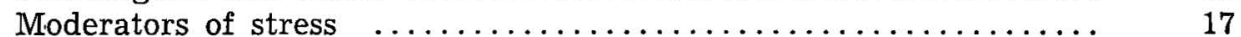

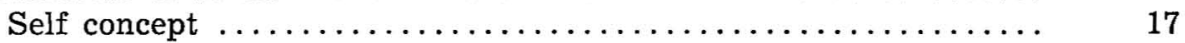

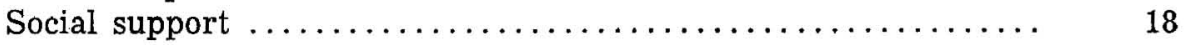

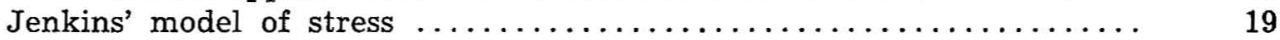

General aspects of the model ........................... 19

Evaluation of the model .............................. 21

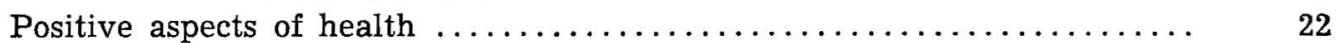

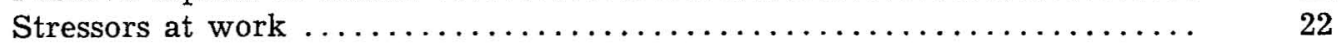

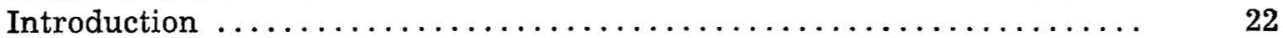

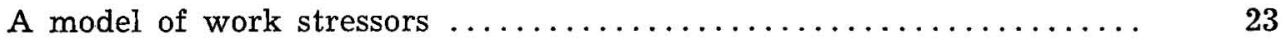

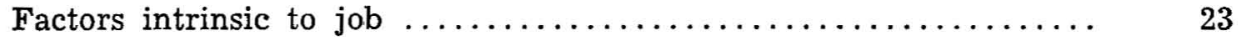

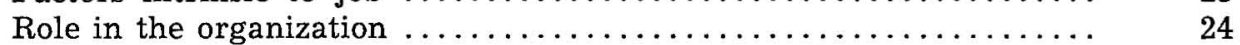

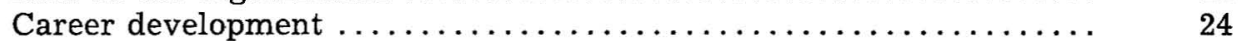

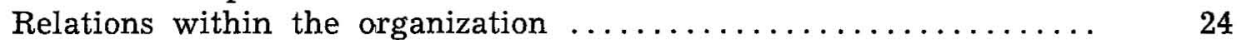

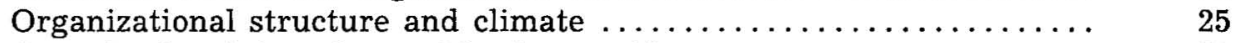

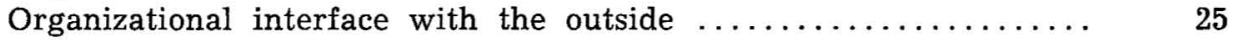

Concept of job satisfaction $\ldots \ldots \ldots \ldots \ldots \ldots \ldots \ldots \ldots \ldots \ldots \ldots \ldots \ldots \ldots \ldots \ldots, \quad 25$

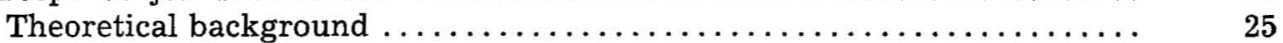

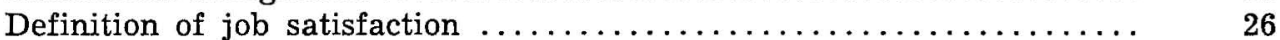

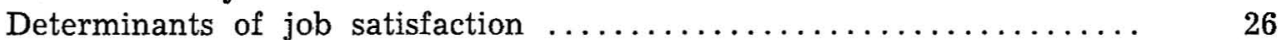

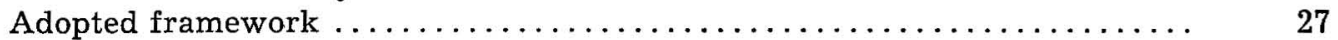

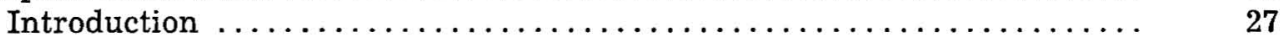

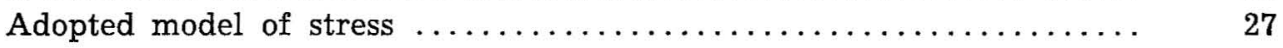

\section{Previous findings}

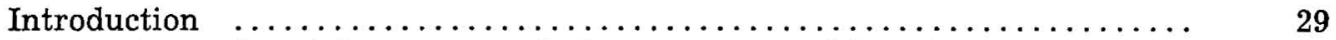

Occupation and social status in relation to stress and health $\ldots \ldots \ldots \ldots \ldots . \quad 30$

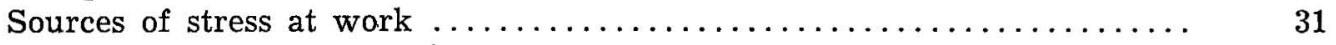

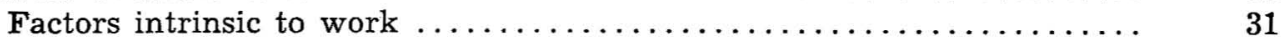

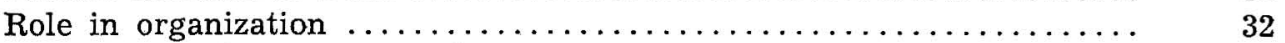

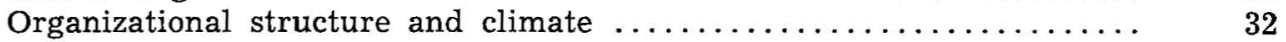

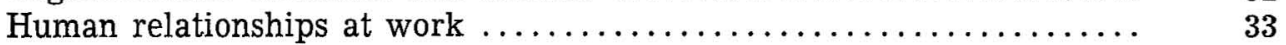

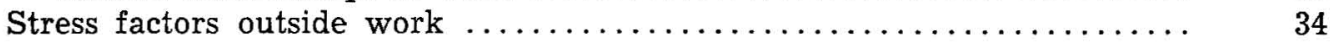




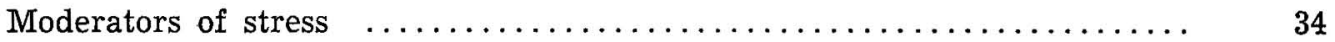

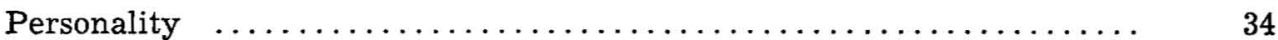

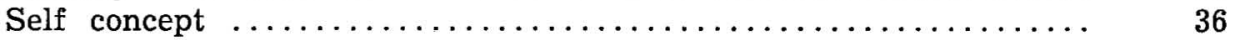

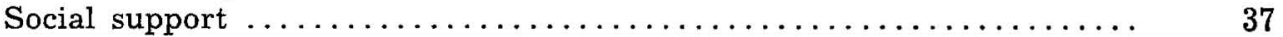

Previous studies on prison personnel $\ldots \ldots \ldots \ldots \ldots \ldots \ldots \ldots \ldots \ldots \ldots \ldots, \quad 38$

\section{Prison organization and function}

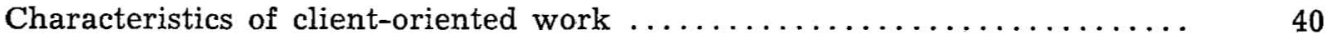

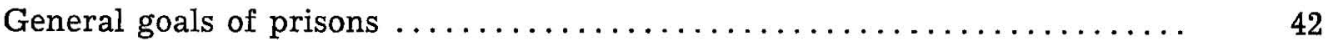

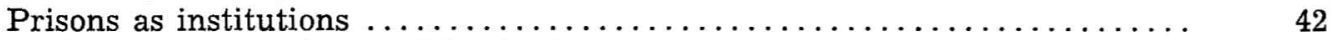

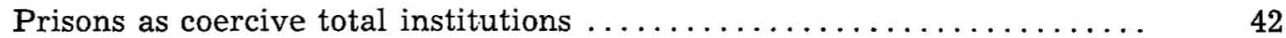

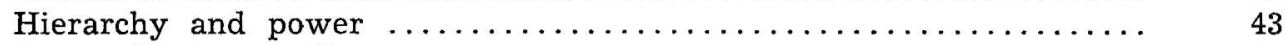

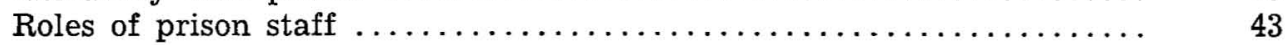

Central feature of work - Interpersonal relation ............... 43

Organization of prisons and their function in Finland $\ldots \ldots \ldots \ldots \ldots \ldots \ldots$

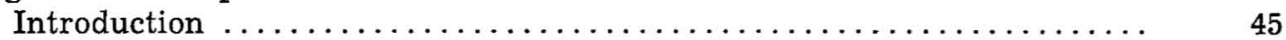

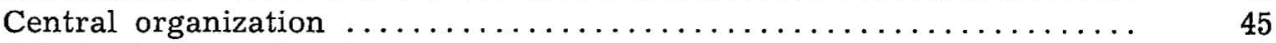

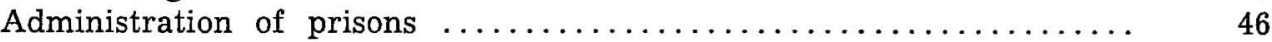

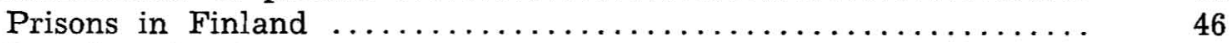

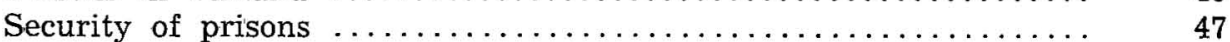

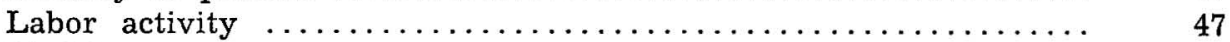

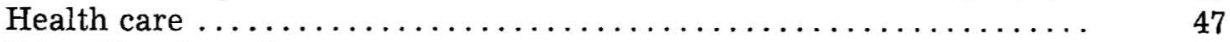

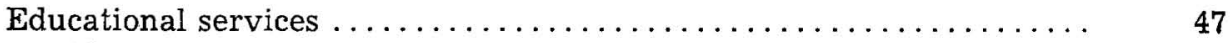

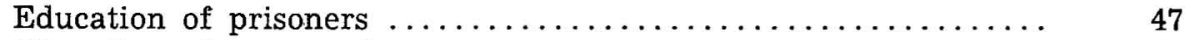

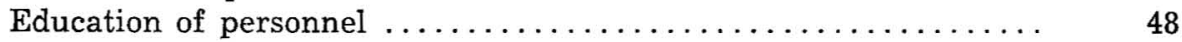

Prison buildings and their development $\ldots \ldots \ldots \ldots \ldots \ldots \ldots \ldots . \ldots \ldots$

\section{Material and methods}

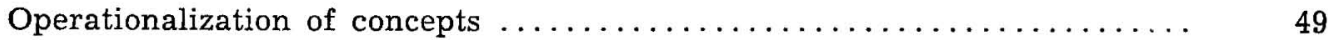

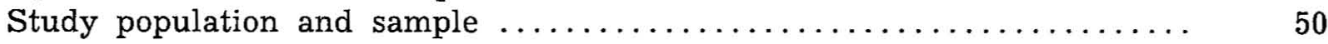

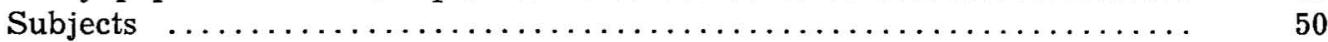

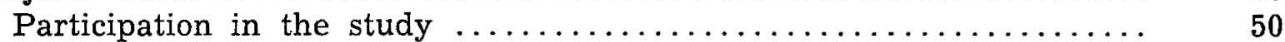

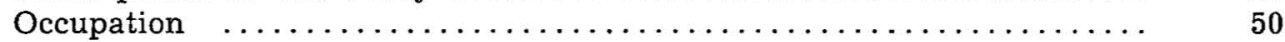

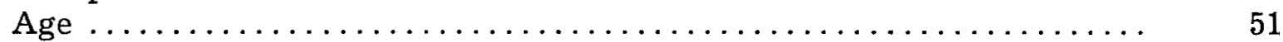

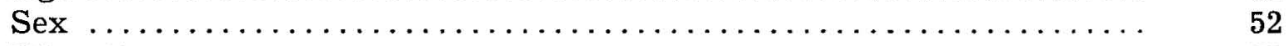

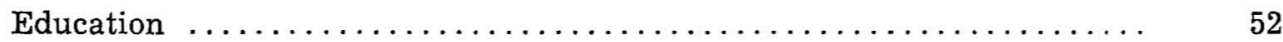

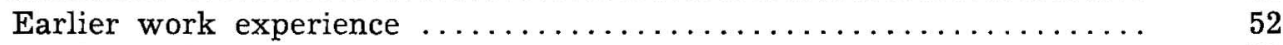

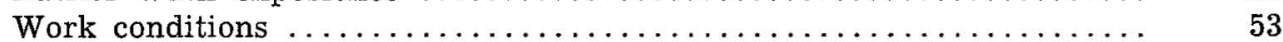

Tasks and work placement of guards and work foremen ......... 53

Relative number of staff to prisoners $\ldots \ldots \ldots \ldots \ldots \ldots \ldots \ldots \ldots \ldots$

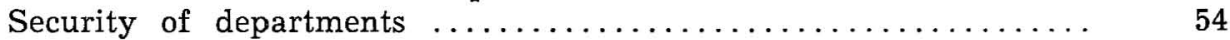

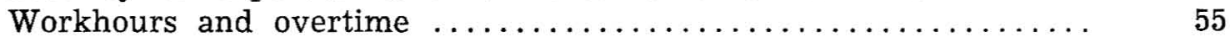

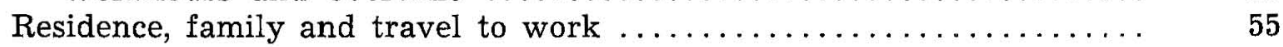

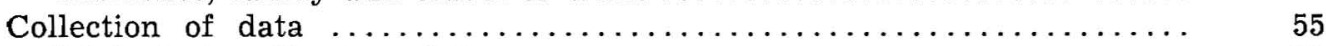

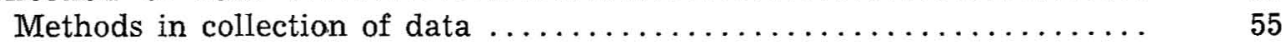

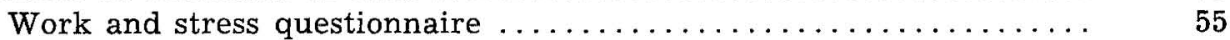

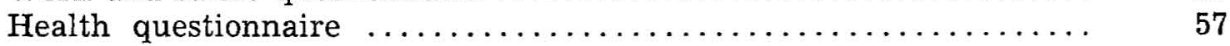

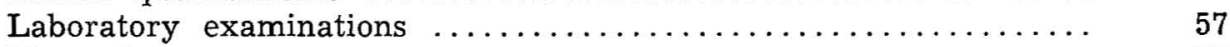

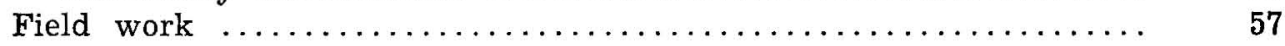

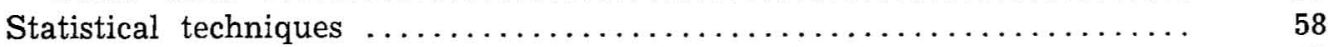

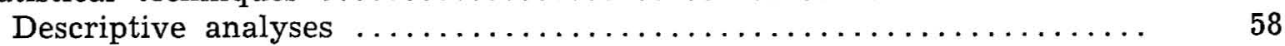

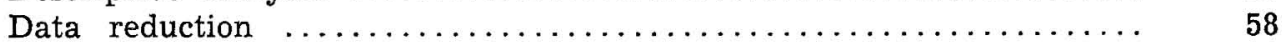

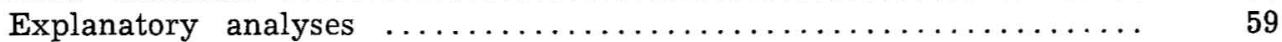

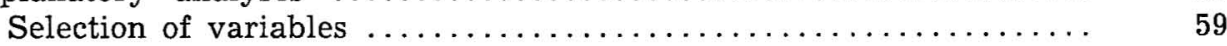

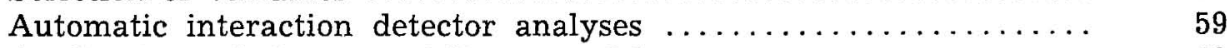

Applications of the general linear model $\ldots \ldots \ldots \ldots \ldots \ldots \ldots \ldots .60$ 


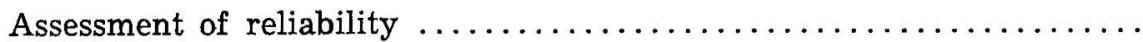

\section{Results}

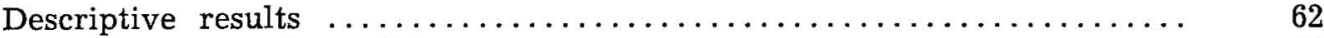

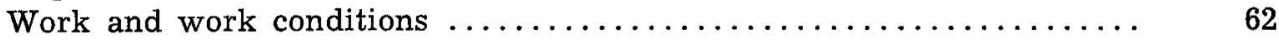

Job satisfaction $\ldots \ldots \ldots \ldots \ldots \ldots \ldots \ldots \ldots \ldots \ldots \ldots \ldots \ldots \ldots \ldots \ldots$

Stress reactions and health status $\ldots \ldots \ldots \ldots \ldots \ldots \ldots \ldots \ldots \ldots \ldots \ldots \ldots . \ldots \ldots$

Perceived symptoms $\ldots \ldots \ldots \ldots \ldots \ldots \ldots \ldots \ldots \ldots \ldots \ldots \ldots \ldots \ldots$

Laboratory examinations $\ldots \ldots \ldots \ldots \ldots \ldots \ldots \ldots \ldots \ldots \ldots \ldots \ldots \ldots \ldots \ldots$

Positive aspects of health $\ldots \ldots \ldots \ldots \ldots \ldots \ldots \ldots \ldots \ldots \ldots \ldots \ldots \ldots$

Stress reactions and health status by occupation, age and length of

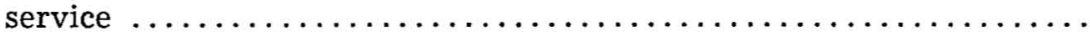

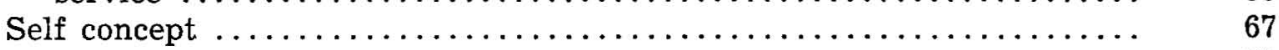

Data reduction $\ldots \ldots \ldots \ldots \ldots \ldots \ldots \ldots \ldots \ldots \ldots \ldots \ldots \ldots \ldots \ldots \ldots \ldots \ldots \ldots \ldots$

Work characteristics $\ldots \ldots \ldots \ldots \ldots \ldots \ldots \ldots \ldots \ldots \ldots \ldots \ldots \ldots \ldots \ldots$

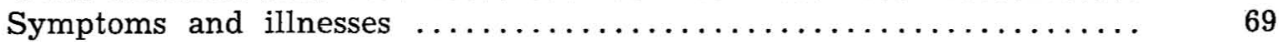

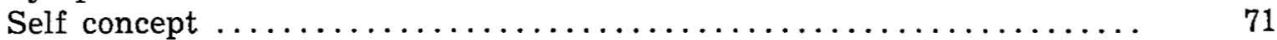

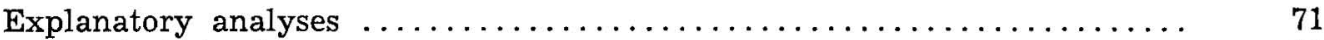

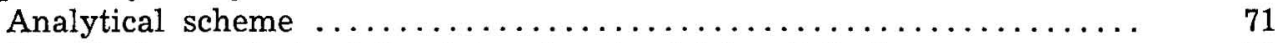

Correlation analysis of the determinants of job satisfaction ........ 72

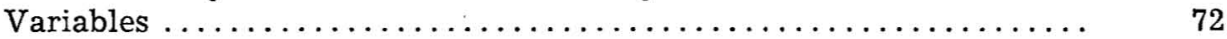

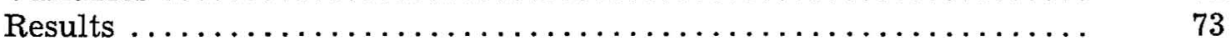

Discussion $\ldots \ldots \ldots \ldots \ldots \ldots \ldots \ldots \ldots \ldots \ldots \ldots \ldots \ldots \ldots \ldots \ldots \ldots$

Relation of stress and health to background factors: Automatic interac-

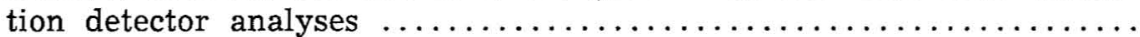

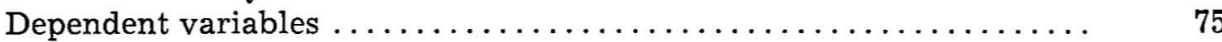

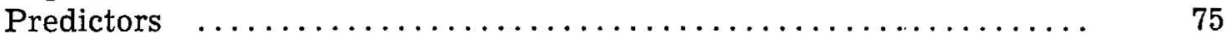

Relation of symptoms to background factors $\ldots \ldots \ldots \ldots \ldots \ldots \ldots$

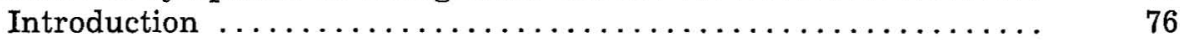

Results $\ldots \ldots \ldots \ldots \ldots \ldots \ldots \ldots \ldots \ldots \ldots \ldots \ldots \ldots \ldots \ldots \ldots \ldots$

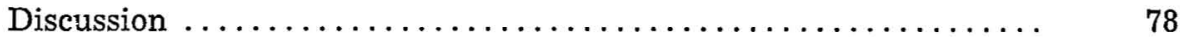

Relation of perceived health status to background factors . . . . . 79

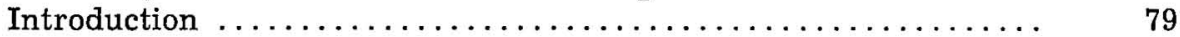

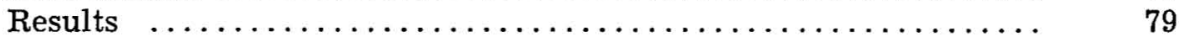

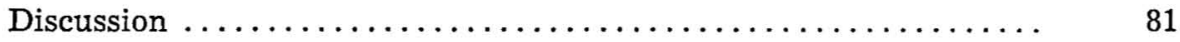

Relation of diastolic blood pressure to background factors ....... 81

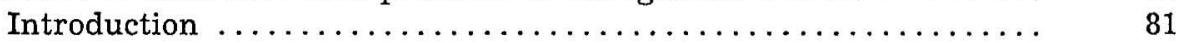

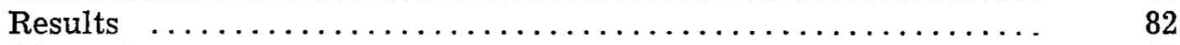

Discussion .............................. 83

Relation of social activeness to background factors $\ldots \ldots \ldots \ldots \ldots . \ldots 3$

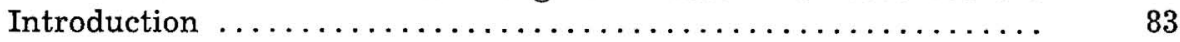

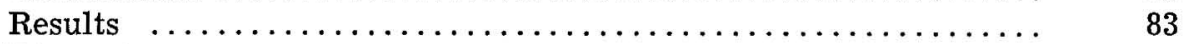

Discussion $\ldots \ldots \ldots \ldots \ldots \ldots \ldots \ldots \ldots \ldots \ldots \ldots \ldots \ldots \ldots \ldots$

Conclusions based on the automatic interaction detector analyses ... $\quad 85$

Final analyses with the general linear model $\ldots \ldots \ldots \ldots \ldots \ldots \ldots \ldots$

Dependent variables $\ldots \ldots \ldots \ldots \ldots \ldots \ldots \ldots \ldots \ldots \ldots \ldots \ldots \ldots \ldots$

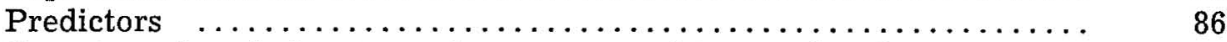

Symptoms in relation to work stressors and interacting factors . . . . 87

Results of the general linear model analysis $\ldots \ldots \ldots \ldots \ldots \ldots \ldots . \ldots 7$

Discussion ............................... 88

Perceived health status in relation to work stressors and interacting

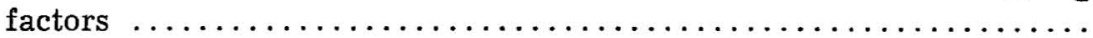

Results of the general linear model analysis

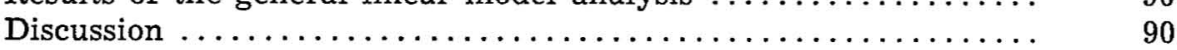

Blood pressure and serum cholesterol in relation to work stressors and interacting factors $\ldots \ldots \ldots \ldots \ldots \ldots \ldots \ldots \ldots \ldots \ldots \ldots \ldots \ldots \ldots \ldots$ 


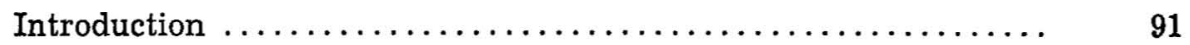

Results of the general linear model analysis $\ldots \ldots \ldots \ldots \ldots \ldots \ldots .92$

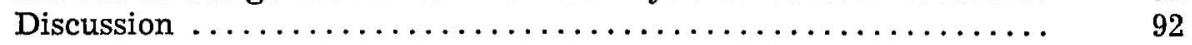

$\begin{array}{ll}\text { Social activeness in relation to work stressors and interacting factors } & 92\end{array}$

Results of the general linear model analysis $\ldots \ldots \ldots \ldots \ldots \ldots \ldots . \ldots 2$

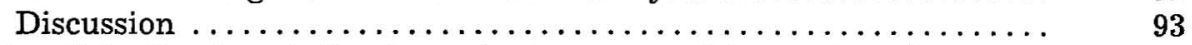

Job satisfaction in relation to work stressors and interacting factors -

An additional test of the framework of the study $\ldots \ldots \ldots \ldots \ldots \ldots$

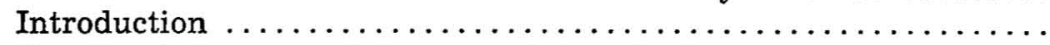

Results of the general linear model analysis $\ldots \ldots \ldots \ldots \ldots \ldots$

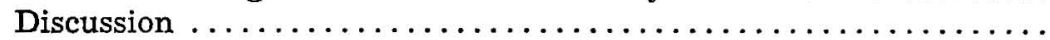

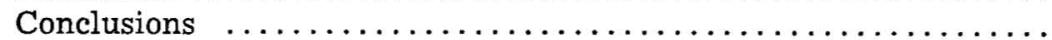

VII Discussion and conclusions

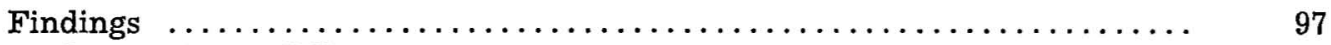

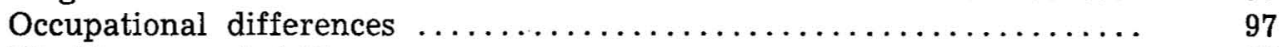

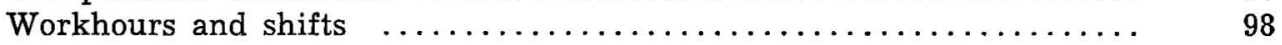

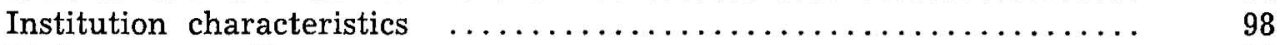

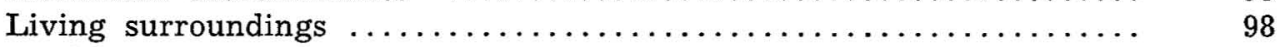

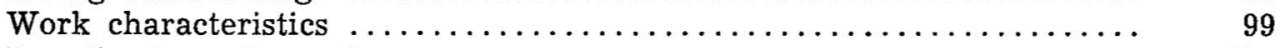

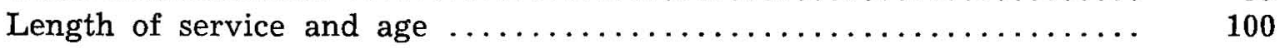

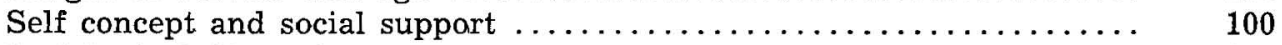

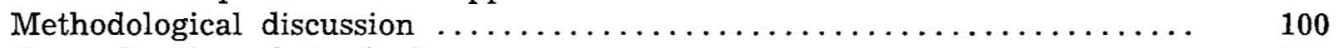

Generalization of the findings $\ldots \ldots \ldots \ldots \ldots \ldots \ldots \ldots \ldots \ldots \ldots \ldots \ldots \ldots \ldots \ldots$

$\begin{array}{ll}\text { VIII Summary } & 103\end{array}$

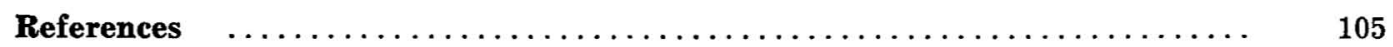

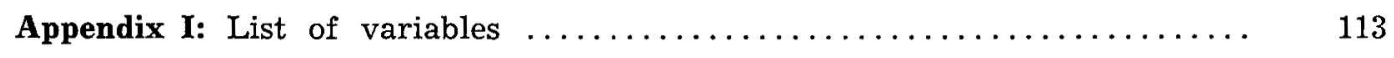

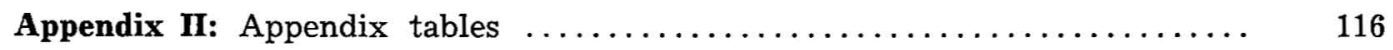

Appendix III: Predictors used in the general linear model analyses ....... 124

Appendix IV: Work and stress questionnaire, with the marginal distributions of the data for the questions used in the present report ${ }^{\mathrm{a}} \ldots \ldots \ldots \ldots \ldots \ldots$

Appendix V: The parts of the health questionnaire used in the present report,

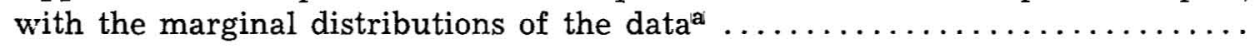

a Appendices IV and V are included only in the copies distributed in connection with the author's doctoral dissertation, and they, therefore, do not appear in the copies distributed through the Scandinavian Journal of Work, Environment \& Health. The appendices are, however, available from the author upon request. 


\section{Introduction and objectives}

\section{STUDY BACKGROUND}

Research on stress has come to be one of the ways man uses to determine those factors in his living environment that have an effect on his well-being. In this work, the main focus has long been on the physical and biological aspects of man's environment as possible sources of disease agents and other health risks. The realization that these factors could explain only a part of the health problems of man has resulted in a widened perspective of the range of environmental health risks.

Another trend of health research has led to the same perspective. It is a change in the conceptualization of health and illness. The more that health disturbances have been seen as processes rather than as things that man either has or has not, the more his own role in the development of health disturbances has been stressed. These trends of thinking have led to an emphasis on symbolic stimuli, subjective experiences of the environment, and the resulting psychophysiological states as possible determinants of a lowered level of well-being. Stress theory has increasingly been applied in the analysis of this process.

Work life is one of the environments of man which is of interest from this new point of view. The emphasis on work as a possible source of stress can be drawn from the great role that work plays in the lives of adults. Work environments vary greatly as sources of experiences, depending on the quality of work and the work environment itself and on the many different ties work has with other phases of life. Work done in closed institutions has certain special characteristics in any of these aspects.

In spite of active research on the structure and function of closed institutions in various countries, relatively minor attention has been paid to the well-being of the personnel in these institutions. The personnel, however, play a crucial role in affecting many people's lives.

Only a few descriptive studies have been carried out in prisons. Analytical studies with a theoretical basis are scarce. Prison personnel, working in coercive total institutions among people deviating from the accepted social norms, are, however, an important target for a study on health and its work-related determinants.

\section{Prison personnel as an object of study}

In fulfilling its goals, the prison has two tasks that are contradictory in many respects. The first is to maintain safety and order, and the second is to try to improve the social and individual resources of the prisoners so that they may manage better as members of society. Prison personnel are in a central position in the accomplishment of the social function of the prison.

The relative importance of the two tasks of prisons has not been agreed upon. These tasks are at least somewhat controversial. If a conflict arises between the tasks, safety and order is usually preferred. This preference is reflected in the structure of prison personnel. The largest group is the guarding staff, whose main task is the maintenance of security and order. The tasks of the teaching and nursing personnel are characterized by rehabilitative functions. The tasks are not, however, completely separated in practice. Some overlapping is a common situation, but it is based mostly on unofficial practical matters instead of formal rules. The difference between official rules and unofficial practice causes conflict in staff roles.

As total institutions the prisons also employ personnel other than staff responsible for safety and rehabilitation. The general features of a closed, total institution and often aggravated social isolation are common aspects of the work environ- 
ment of the whole prison staff. A continuous demand for alertness due to the nature of the work is a special characteristic of prison service. In this field of work, like in many other types of service occupations, health, social care, and education, especially the psychological and social factors of the work environment are possible sources of occupational stress and resulting health problems.

On the whole, the stress factors in the work environment of prison personnel are thought to be primarily due to the structure of the organization, leadership style, work content, and human relations at work.

An orientating survey on the perceived weaknesses of the work and work conditions in prisons was carried out in 1972 by the Prison Department of the Ministry of Justice in Finland. The survey also dealt with the personnel's subjective views of their health status. The results indicated that a considerable number of problems are perceived in the work conditions. The high mental load of the work was the most prominent factor in the evaluations of the personnel. The greatest problem was the understaffing in comparison to the number of prisoners. Important drawbacks were also ambiguous definitions of the tasks and work roles. Responsibility for the security of others was among the major stressors. The health status was also perceived as unsatisfactory. The most common health problems were an excess of perceived strain, tension, anxiety, and headache. The results revealed that the health services in prisons, which are primarily planned for the prisoners, were not sufficient for the personnel.

It was hypothesized, on the basis of the survey, that the work of prison personnel possibly contains strong sources of stress and that the health problems might be at least partly stress-mediated. The possible sources of stress in work were expected to be primarily psychological and social.

With this hypothesis as a basis, the Prison Department of the Ministry of Justice and the Ministry of Finance in Finland asked the Institute of Occupational Health, Helsinki, to conduct a comprehensive study of the health conditions of prison personnel and their possible risks at work.
Going beyond the practical purposes required by the Prison Administration, the study of prison personnel was expected to offer a possibility to investigate the relationships between work, stress and health in a more generalized way in an occupational field suspected to be highly stressful.

According to these general considerations, a study of the work conditions, job satisfaction, stress, and health status was carried out by the Institute of Occupational Health. The descriptive findings of the study have been reported in Finnish (135, 136) for practical application in occupational health care and as a basis for changes to be made in the workplaces. The analytical part of the study is presented in this report.

\section{SPECIFIC OBJECTIVES OF THE STUDY}

The study was expected to provide information about the work-related factors that cause stress and affect health status among personnel in prisons, a prominent type of closed coercive institution. Work in prisons is thought to be stress provoking. Thus it offers an adequate target for the application of the stress theory in the study of the relationships between work and health.

Another aim of this investigation was to study the feasibility of the general work-related stress factors and certain specific features of client-oriented work in the explanation of stress reactions and health disturbances.

As individual reactions are known to vary under exposure to any environmental conditions, the possible interacting effects, either predisposing or protective, of individual backgrounds, personality characteristics, and perceived social support were also studied.

The relationships between job satisfaction and stress at work have not been studied to a great extent, and also the corresponding theory is vague. In this respect the purpose was to study the feasibility of a model in which job dissatisfaction is considered an intermediary phase in the development of stress.

Finally, an attempt was made to draw conclusions about the sources of stress in work in closed institutions and to discuss 
their generalizations to certain aspects of any client-oriented work in the fields of health and social care.

To summarize, the overall objective of the present study was to carry out an analytical investigation of the relationships between work, job satisfaction, stress, and health in a closed institution and to discuss the findings within the framework of a psychological theory of stress at work. For this purpose the following questions were studied and discussed: (i) What are the determinants of stress reactions at work? (ii) What is the relation of stressinduced health problems to work and the occupational background? (iii) What is the role of job dissatisfaction in the development of stress at work? (iv) What is the interactive effect of personality and other individual factors and social support on the relationships between work, job satisfaction, stress, and health?

\section{STRUCTURE OF THE REPORT}

In view of the previously described objectives, the report discusses, first in part II, the theoretical framework of the study, covering a conceptual analysis and the general stress theory. This part also includes an overview of the sources of stress at work. At the end of part II the adopted framework for the empirical part of the study is presented.

In part III a selective review of relevant previous findings on occupational stress is given. This part also includes literature on the modifiers of stress. Previous studies on prison personnel are described separately.
Work in prisons is, to a large extent, client-oriented work. The specific characteristics of various types of client work are analyzed in the beginning of part IV. An attempt is made to schematize the crucial dimensions of client-oriented work that cause similarities and differences in various fields. The main content of part IV is a description of prisons and work in prisons and a presentation of the Finnish prison organization. This part is written to highlight the institutional background of prison work. It is supposed to aid the understanding of this report by those who know very little about prisons and those who are familiar with the general aspects of prisons and want to know the details of the Finnish prison organization.

The study population and sample are chanacterized in part $V$. This part also includes a description of the methods of the study.

The results are presented in part VI. Summaries of the descriptive results on work, stress, health and personality characteristics, which have been reported elsewhere, are given in the beginning of this section. The reduction of data is described on this basis. The main content of this part of the report is formed of the results of the multivariate analyses with job satisfaction, stress reactions and health indicators as dependent variables and work characteristics and individual factors as predictors. The results are discussed after the presentation of each analysis.

The general discussion of the applied theory, methods and results, as well as conclusions drawn on the basis of the results, are included in part VII, which is followed by a summary of the study, part VIII. 